\title{
Optimization for an Anaerobic Reactor for Treatment of Industrial Wastewater
}

\author{
P.Teli ${ }^{1}$, Prof P.Raut ${ }^{2}$ \\ 1(Student,M.Tech (Env.Sci. and Tech), Department of Env.Sci. and Tech, Shivaji University, Kolhapur (MH) \\ 2(Professor, Department of Env.Science, Shivaji University, Kolhapur (MH)
}

\begin{abstract}
In any dairy plant, the quantity and characteristics of effluent is depending upon the extent of production activities, pasteurization to several milk products. Water management in the dairy industry is well documented, but effluent production and disposal remain a problematic issue for the dairy industry .To enable the dairy industry to contribute to water conservation, an efficient and cost-effective treatment technology has to be developed. The anaerobic reactors in the first phase of treatment, which is followed by high rate aerobic treatment, remain as the most common effluent treatment scheme for dairy plants. The dairy industries require large quantity of water for the purpose of washing of cans, machinery and floor, the liquid waste in a dairy originates from manufacturing process, utilities and service section. So there is every need to reuse the waste water generated with proper and efficient treatment methods. The present study, thus initiated, for evaluating a need of experimental work on anaerobic reactor incorporated with fixed and floating film system for treating dairy wastewater with four weeks of harvesting. The kinetic parameters are estimated using the experimental data to develop model. Empirical relations were generated for the characteristics like COD, BOD, and TSS using modeling equations
\end{abstract}

\section{INTRODUCTION}

Water management in the dairy industry is well documented, but effluent production and disposal remain a problematic issue for the dairy industry .To enable the dairy industry to contribute to water conservation, an efficient and cost-effective treatment technology has to be developed. To this effect anaerobic digestion offers a unique treatment option to dairy industry. Not only does anaerobic digestion reduce the COD of an effluent, but little microbial biomass is produced. The biggest advantage is energy recovery in the form of methane and the organic matter in a waste stream can be converted into biogas. Many high-rate digester designs are currently available and some have successfully been used for the treatment of dairy effluents. [1] With the increase in demand for milk and milk products many dairies of different sizes have come up I different places. These dairies collect the milk from the producers and then either simply bottle it for marketing or produce different milk foods according to their capacities. Large quantity of wastewater originates due to their different operations. The organic substances in the wastes comes either in the form in which they were present in milk, or in a degraded form due to their processings. As such the dairy wastes though biodegradable are very strong in nature.

\section{INTRODUCTION TO ANAEROBIC PROCESS}

Anaerobic processes are defined as biological processes in which organic matter is metabolized in an environment free of dissolved oxygen or its precursors (e.g., $\mathrm{H}_{2} \mathrm{O}_{2}$ ). Anaerobic process is classified as either anaerobic fermentation or anaerobic respiration depending on the type of electron acceptors. Anaerobic digestion refers to the anaerobic decomposition of organic matter, resulting impartial gasification, liquefaction, and mineralization. [4] The anaerobic digestion process and production of methane is divided into stages. Three stages often are used to illustrate the sequence of microbial events that occur during the digestion process and the production of methane. These stages are Hydrolysis, acid formation and methanogenesis. The anaerobic digestion process contains different groups of bacteria. These groups work in sequence with the products of one group serving as the substrates of another group.

\section{OBJECTIVES}

- To study physico-chemical characteristics of wastewater.

- To develop a mathematical model of anaerobic digestion process.

- To design for Fixed Film Type and Floating Type Media based reactors for industrial effluent treatment.

- To determine differences between the fixed film and floating media phases for each reactor. 


\section{MATERIAL USED}

The effluent which is the wastewater was collected from the dairy industry. The collected sample was kept in plastic cans in a freezer at room temperature and was studied for its characteristics.

\subsection{METHOD TO BE ADOPTED:}

For the work anaerobic culture was collected from local market. The unit is first acclimatized to the conditions by feeding specific quantity of anaerobic culture at regular designated intervals of time, so that the reactor gradually gets used to the type of wastewater to be subjected to it. There are two types of media are provided in fixed and floating film media.

\subsection{DESCRIPTION OF MEDIA:}

$>$ Fixed film media dimensions are $27 \times 37 \mathrm{~cm}$

$>$ Floating film media dimensions are $2 \times 1.5 \mathrm{~cm}$

\subsection{DESCRIPTION OF ANAEROBIC REACTOR:}

$\begin{array}{lcc}>\text { Reactor height } & : & 49 \mathrm{~cm} \\ >\text { Stand for reactor } & : & 13.5 \mathrm{~cm} \\ >\text { Inlet funnel cone diameter } & : & 16 \mathrm{~cm} \\ \text { > Outlet height from bottom of reactor } & : & 40 \mathrm{~cm} \\ >\text { Inlet diameter } & : & 2.5 \mathrm{~cm} \\ >\text { Outlet diameter } & : & 1.8 \mathrm{~cm} \\ >\text { Inlet height from bottom of reactor } & : & 3 \mathrm{~cm}\end{array}$

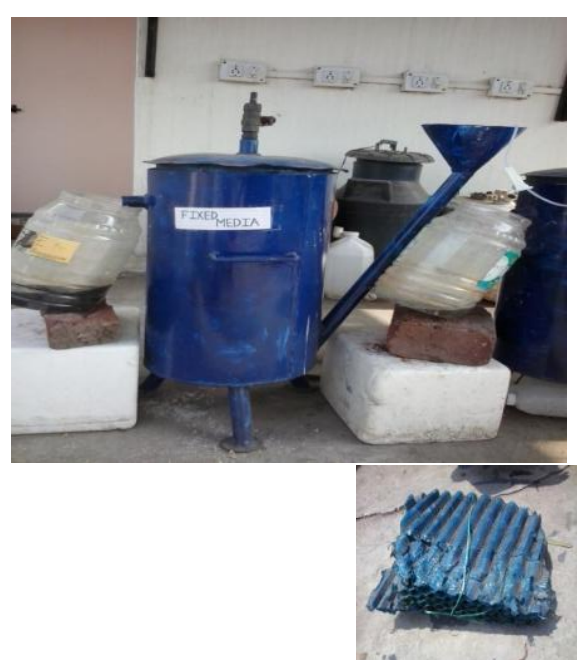

(a) Fixed

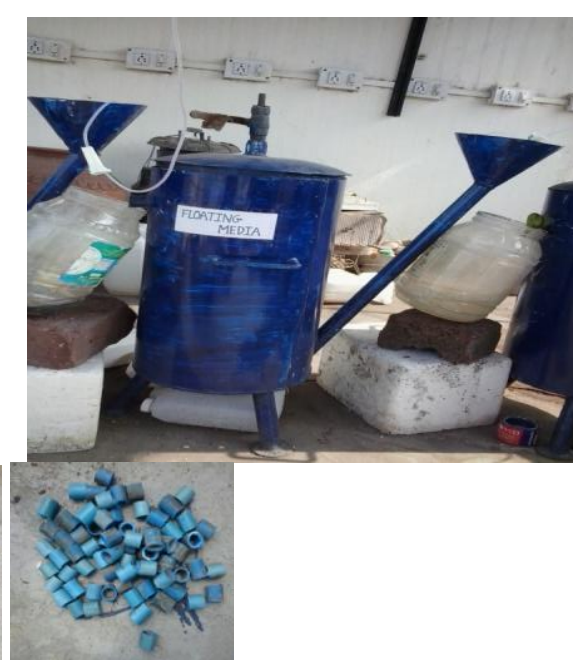

(b) Floating

Figure 1 - Anaerobic reactor with fixed and floating media

\section{RESULT}

The wastewater was collected from the dairy industry. The wastewater was analyzed for their characteristics. The dairy wastewater sample was carried out to determine general characteristics. The results obtained are shown in Table 1.

Table 1 - General characteristics of dairy effluent

\begin{tabular}{|c|c|c|}
\hline Parameter & Unit & Value \\
\hline $\mathrm{pH}$ & - & $4.22-5.36$ inlet \\
\hline $\mathrm{COD}$ & $\mathrm{Mg} /$ lit & $1499-1680$ inlet \\
\hline Colour & - & Whitish \\
\hline
\end{tabular}

VI. DISCUSSION - START-UP OF THE REACTOR

The reactor was initially filled with anaerobic culture with wastewater and media is provided in the reactor 
The procedure was carried out in two phases. The first phase consisted of Stabilization of the reactor by the addition of anaerobic culture quantity, and the second phase consist of the actual study.

As shown in fig. 2 when number of days increases with increase in COD at inlet and decreases COD at the outlet of reactor in both media and the number of days increases with increase in HRT lit/day. The HRT lit/day was stretched to certain higher rates to observe the effect. COD increases with the number of day's for the reactor was achieved for fixed film media 87 to $91 \%$ (at a change in HRT per $24 \mathrm{hrs} 5.30$ to $5.90 \mathrm{~m}^{3} /$ day) as compare to floating film media 84 to $86 \%$ (at a change in HRT per $24 \mathrm{hrs} 5.30$ to $5.90 \mathrm{~m}^{3} /$ day).

\subsection{MATHEMATICAL MODELING}

From the study, the Modified Velz equation was adopted as a baseline model due to the fact that it bore the closest relevance to the project under consideration. On the basis of this model as a base, several more models were studied and finally, an Eqution developed by Germain (1966) and Schultz (1960) was adopted, which has a similarity with the modified Velz equation. The equation that was stated by the above mentioned scientists is as follows:

\section{i) Treatability Constant}

$$
\frac{S_{e}}{S_{i}}=\exp \left[-k D\left(Q_{v}\right)^{-n}\right]
$$

Where,

$\mathrm{S}_{\mathrm{e}}=$ Total $\mathrm{BOD}_{5}$ of Settled Effluent from the reactor, $\mathrm{mg} / \mathrm{L}$

$\mathrm{S}_{\mathrm{i}}=$ Total $\mathrm{BOD}_{5}$ of wastewater subjected to the reactor, $\mathrm{mg} / \mathrm{L}$

$\mathrm{k}=$ Treatability Constant, $(\mathrm{L} / \mathrm{sec})^{\mathrm{n}}$. $\mathrm{m}$

$\mathrm{D}=$ Depth of the Media, $\mathrm{m}$

$\mathrm{Q}=$ Volumetric Flow Rate, $\mathrm{L} / \mathrm{sec}$

$\mathrm{Q}_{\mathrm{v}}=$ Volumetric Flow Rate applied per unit volume of reactor, $\mathrm{L} / \mathrm{m}^{2}$.sec

$\mathrm{A}=$ Cross-sectional area of the reactor, $\mathrm{m}^{2}$

$\mathrm{n}=$ experimental constant, usually 0.5

ii) Reaction Rate Constant

$$
\frac{S_{e}}{S_{i}}=\exp \left[-K S_{a}^{m} D\left(Q_{v}\right)^{-n}\right]
$$

Where,

$\mathrm{K}=$ Observed reaction rate constant for a given depth of the reactor, $\mathrm{m} /$ day

$\mathrm{D}=$ Depth of the reactor, $\mathrm{m}$

$S_{a}=$ Specific surface area of the filter media

$$
=\frac{\text { Surface Area of the Filter,(As),m }}{\text { Unit Volume, } \mathrm{m}^{3}}
$$

$\mathrm{Q}_{\mathrm{v}}=$ Volumetric Flow Rate applied to the reactor, $\mathrm{m}^{3} / \mathrm{m}^{2} . \mathrm{d}$

$\mathrm{Q}=$ Flow Rate applied to the reactor, $\mathrm{m}^{3} / \mathrm{d}$

$\mathrm{A}=$ Cross-sectional area of the reactor, $\mathrm{m}^{2}$

$\mathrm{m}, \mathrm{n}=$ empirical constants

1) The filter treatability Constant for Anaerobic reactor treating Dairy effluent with fixed film media is 5.5 x $10^{-3}(\mathrm{~L} / \mathrm{sec})^{\mathrm{n}}$.m.The Reaction Rate Constant is $8.30 \times 10^{-3} \mathrm{~m} /$ day.

2) The filter treatability Constant for Anaerobic reactor treating Dairy effluent with floating film media is

\begin{tabular}{|c|c|c|c|c|c|c|c|c|c|}
\hline \multirow[t]{2}{*}{ Day } & \multicolumn{2}{|c|}{ HRT lit per day } & \multicolumn{2}{|c|}{ Efficiency (\%) } & \multirow[t]{2}{*}{ Day } & \multicolumn{2}{|c|}{ HRT lit per day } & \multicolumn{2}{|c|}{ Efficiency (\%) } \\
\hline & Fixed & Floating & Fixed & Floating & & Fixed & Floating & Fixed & Floating \\
\hline 1 & 0.50 & 0.50 & 3.86 & 1.78 & 16 & 3.50 & 3.50 & 80.3 & 65.53 \\
\hline 2 & 0.70 & 0.70 & 7.83 & 5.42 & 17 & 3.70 & 3.70 & 80.74 & 67.9 \\
\hline 3 & 0.90 & 0.90 & 3.26 & 3 & 18 & 3.90 & 3.90 & 81.31 & 69.36 \\
\hline 4 & 1.10 & 1.10 & 15.85 & 7.31 & 19 & 4.10 & 4.10 & 81.64 & 71.51 \\
\hline
\end{tabular}
$4.7 \times 10^{-3}(\mathrm{~L} / \mathrm{sec})^{\mathrm{n}}$.m. The Reaction Rate Constant is $16.78 \times 10^{-3} \mathrm{~m} /$ day

Table 2 - Analysis Chart 


\begin{tabular}{|l|l|l|l|l|l|l|l|l|l|}
\hline 5 & 1.30 & 1.30 & 23.83 & 15.56 & 20 & 4.30 & 4.30 & 82.89 & 69.18 \\
\hline 6 & 1.50 & 1.50 & 40.77 & 17.85 & 21 & 4.50 & 4.50 & 83 & 79.08 \\
\hline 7 & 1.70 & 1.70 & 52.15 & 28.22 & 22 & 4.70 & 4.70 & 83.13 & 78.91 \\
\hline 8 & 1.90 & 1.90 & 54.54 & 32 & 23 & 4.90 & 4.90 & 84.96 & 80.53 \\
\hline 9 & 2.10 & 2.10 & 57.1 & 41.86 & 24 & 5.10 & 5.10 & 86.79 & 83.64 \\
\hline 10 & 2.30 & 2.30 & 57.14 & 48.75 & 25 & 5.30 & 5.30 & 87.69 & 84.85 \\
\hline 11 & 2.50 & 2.50 & 54.72 & 49.32 & 26 & 5.50 & 5.50 & 88.02 & 85.42 \\
\hline 12 & 2.70 & 2.70 & 65.31 & 56.93 & 27 & 5.70 & 5.70 & 89.74 & 85.89 \\
\hline 13 & 2.90 & 2.90 & 69.5 & 62.89 & 28 & 5.90 & 5.90 & 91.08 & 86.62 \\
\hline 14 & 3.10 & 3.10 & 73.64 & 60.47 & 29 & 6.10 & 6.10 & 88.92 & 84.49 \\
\hline 15 & 3.30 & 3.30 & 79.52 & 64.7 & 30 & 6.30 & 6.30 & 85.88 & 81.59 \\
\hline
\end{tabular}
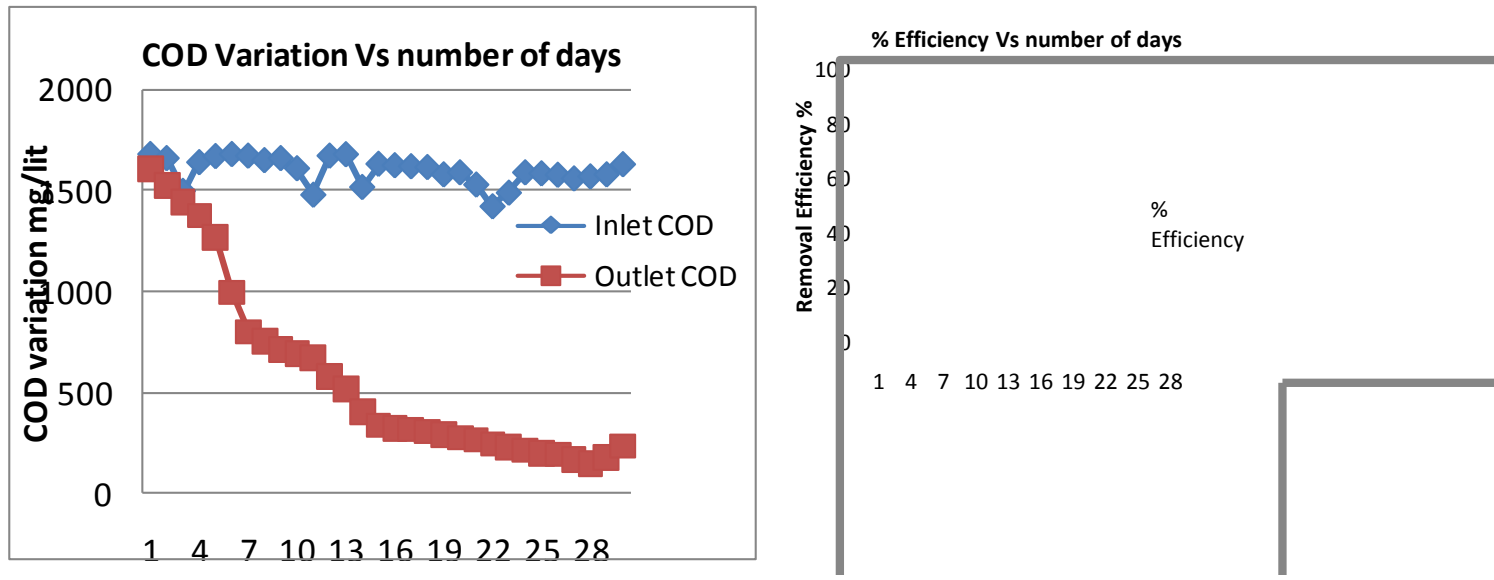

(A) Fixed media
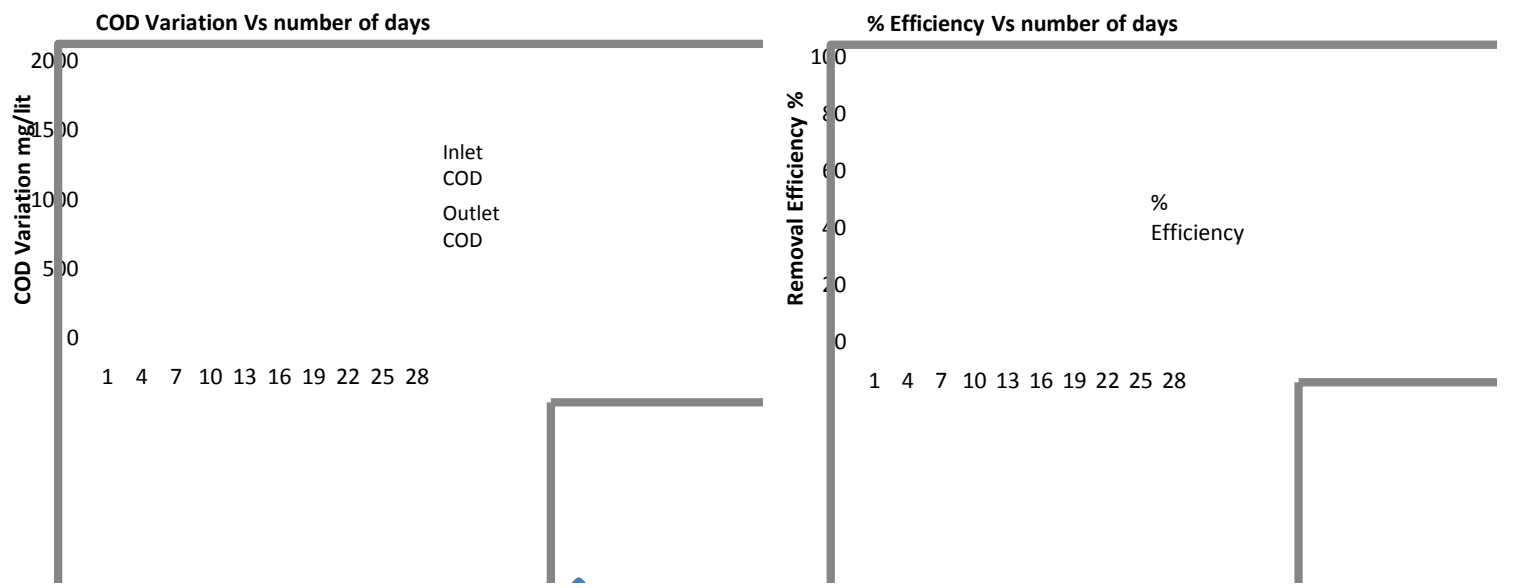

(B) Floating media

Figure 2 - (A) and (B) COD Variation Vs number of days and \% efficiency Vs number of days

VII. CONCLUSION

According to the results obtained elimination of COD increases with the number of day's for the reactor was achieved for fixed film media 87 to $91 \%$ (at a change in flowrate per $24 \mathrm{hrs} 5.30$ to $5.90 \mathrm{~m}^{3} / \mathrm{day}$ ) as compare to floating film media 84 to $86 \%$ (at a change in flowrate per $24 \mathrm{hrs} 5.30$ to $5.90 \mathrm{~m}^{3} / \mathrm{day}$ ). The anaerobic reactor can be effectively used for the treatment of dairy effluent. By using the mathematical model suitably designed for dairy effluent designing of an anaerobic reactor for depth and efficiency criteria is possible. 


\section{ACKNOWLEDGEMENTS}

This is for the firm assertion of the concerned authorities that the dissertation work entitled "Model based Optimization for anaerobic reactor for treatment of industrial wastewater" has been completed by the undersigned strictly on an individual basis for the fulfillment of the requirements for the award of "Master of Technology" in Environmental Science and Technology, under Shivaji University, Kolhapur, during the year 2013-2014.

\section{Journal Papers:}

\section{REFERENCES}

[1] Dwaraka K., Meena V.2010, "Kinetic Studies on Dairy Wastewater Using Immobilized Fixed Bed Anaerobic Digester" International Journal of Chemical Environment and Pharmaceutical Research Vol-1(1) No.1,1-5

[2] Dwaraka K., JayaRaju.K 2010 "Municipal Wastewater Treatment And Kinetic Studies Using Immobilized Fixed Bed Anaerobic Digester" IJABPT Vol I 921-925.

[3] Sagar A., V.S.Kore., S.V.Kore., Prof G.S.Kulkarni and Prof S.V.Ranade 2011 "Optimization Of Reaction Kinetics For Anaerobic Filter With Reference to distillery Condensate Treatment" International Journal of Emerging Technology and Applications in Engineering,Technology and Sciences Vol.4(2) 380-383.

[4] G Srinivasan., R.Suramaniam and V.Nehrukumar., "A Study on Dairy Wastewater Using Fixed Bed Anaerobic Diphasic Digester" American Eurasian Journal of Scientific Research, 2009 Vol.4(2) 89-92.

[5] Sumi S., Mathew L., 2009, "Influence of Media Packing Depth and HRT on Performance of Anaerobic Hybrid Reactors", $10^{\text {th }}$ National Conference on Technology Trends, College of Engineering Trivandrum, pp. $38-41$.

[6] Yilmaz T., Yuceer A., Basibuyuk M., 2006, "A comparison of the performance of mesophillic and thermophillic anaerobic filters treating papermill wastewater", Bioresource Technology, Elsevier Publication, pp. $156-163$.

[7] Santhananthan S., Ching N. L., Ling T. M., Jeyaseelan S., 2009, "Development of Mathematical Model for Anaerobic Digestion by Phase Separation".

[8] Sarti A., Foresti E., Zaiat M., 2004, "Evaluation of a Mechanistic Mathematical Model of a Packed Bed Anaerobic Reactor Treating Wastewater", Latin American Applied Research, Vol. 34, pp. 127 132.

[9] Baez - Smith C., 2006, "Anaerobic Digestion of Vinasse for Production of Methane in the Sugar Cane Distillery", Proceedings of SPRI Conference on Sugar Processing.

[10] Chen Y. and Cheng J. J., 2005, "Anaerobic Processes in Waste Treatment", Water Environment Research, Water Environment Federation Publication, Vol. 77(6), pp. 1347 - 1388.

[11] Bortone G., 2009, "Integrated anaerobic / aerobic biological treatment for intensive swine production", Bioresource Technology, Elsevier Publication, Vol. 100, pp. 5424 - 5430.

[12] Garcia - Ochoa F., Santos V. E., Naval L., Guardiola E., Lopez B., 1999, "Kinetic model for anaerobic digestion of livestock manure", Enzyme and Microbial Technology, Elsevier publications, Vol. 25, pp. $55-60$.

[13] Stover E. L., Reinagldo G., Gonathi N. G., 1984, "Anaerobic Fixed Film Biological Treatment Kinetics of Fuel Alcohol Production Wastewater", Proceedings of $2^{\text {nd }}$ International Conference on Fixed Film Biological Processes, pp. 1625.

[14] Saleh M. M. A. and Mahmood U. F., 2004, "Anaerobic Digestion Technology for Industrial Wastewater Treatment", Proceedings of the Eighth Water Technology Conference, Alexandria Egypt.

[15] Santhananthan S., Ching N. L., Ling T. M., Jeyaseelan S., 2009, "Development of Mathematical Model for Anaerobic Digestion by Phase Separation".

[16] Srisertpol J., Srinakorn P., Kheawnak A., Chamniprasart K. and Srikaew A., 2010, "Estimation Dynamical Model of an Anaerobic Digestion of Shrimp Culture Pond Sediment in Biogas Process using Genetic Algorithm", System Science and simulation in Engineering,pp.449-453

[17] Metcalf and Eddy $4^{\text {th }}$ Edition "Wastewater Engineering: Treatment \& Reuse".

[18] Leong S.,2011, "Determination of Treatability Constant and Reaction rate Constant for an Attached Growth Upflow Fixed Film Reactor on Pulp and Paper Wastewater Treatment",Internationa Journal of Chemical Engineering and Applications, Vol 2(1) 14-19. 